\title{
Dialectic evolution through the social innovation process: from microcredit to microfinance
}

\author{
Arvind Ashta ${ }^{1 *}$, Mawuli Couchoro ${ }^{2}$ and Abu Saleh Mohammad Musa ${ }^{3}$
}

\author{
* Correspondence: \\ Arvind.ashta@escdijon.eu \\ ${ }^{1}$ Holder of the Banque Populaire \\ Chair in Microfinance at the \\ Burgundy School of Business (ESC \\ Dijon-Bourgogne), CEREN, CERMi, \\ 29 rue Sambin, 21000, Dijon, France \\ Full list of author information is \\ available at the end of the article
}

\begin{abstract}
Microfinance is the provision of financial services to the financially excluded, usually the poor. We use literature reviews and descriptive research to present different aspects of the relationship of the microfinancial services to microenterprise. The first thrust in this field had been from microcredit and group lending to encourage business initiatives among the poor. The hope that these services would lift them out of poverty had largely built the brand image of the sector. However, the spread of consumer microcredit and uncontrolled growth of microfinance led to over-lending without adequate checks and balances, leading to over-indebtedness and associated stress, and critique of microcredit. To restore balance, other financial products, such as microequity, microsavings, microinsurance, microguarantees, and microremittances, have been suggested. We place these developments in a social innovation process perspective by showing that microfinance, through its wide range of innovatively distributed products, can be a key factor to foster entrepreneurship.
\end{abstract}

JEL: L26, O16, O17, O30

Keywords: Entrepreneurship; Microcredit; Microequity; Microinsurance; Microsavings; Microremittances; Microguarantee; Innovation

\section{Background}

Addressing poverty is a complex issue. Different researchers and professionals have focused on different tools. For example, De Soto (2000) stresses that the absence of property rights keeps countries from developing, Prahalad (2006) feels that the least of the poor should be targeted as consumers and included into the market, Karnani (2007) feels that there is no fortune at the bottom of the pyramid and the poor need public sector jobs, and Ashta (2013b) feels the need for raising minimum wages for those who already have jobs. Sachs (2005) feels that the very poor are so incapacitated that only donations would help, and Yunus (2003) recommends microcredit. There are many other issues involved such as health and education. All these researchers and practitioners realize that the tool they are focusing on is just one in a bag of tools required to increase the capital of the poor: Since the governments of these countries are poor and cannot provide the basic services such as property rights, adequate public works, or even high-enough minimum wages, one possible solution advocated is selfhelp: for the poor to rise from poverty requires them to become microentrepreneurs and take charge of their own fate. The free market has not solved the problem because entrepreneurship requires financial capital, social capital, and human capital.

(C) 2014 Ashta et al.; licensee Springer. This is an Open Access article distributed under the terms of the Creative Commons Attribution License (http://creativecommons.org/licenses/by/2.0), which permits unrestricted use, distribution, and reproduction in any medium, provided the original work is properly cited. 
A social innovation is therefore required because existing public and private institutions cannot solve the problem. Schumpeter (1935) considers innovation as the production of a new good, the introduction of a new method of production, the opening of a new market, the conquest of a new source of raw material, and the creation of a new organization. Social innovation means that new forms of social relations are required in order to overcome the financial and social exclusion and create empowerment (Moulaert et al. 2013b). Evidently, this requires overcoming conservative forces which would prefer to perpetuate the existing system or try to take over any new system to its own advantage and, thus, either perpetuate the exclusion or find new ways to exploit (Moulaert et al. 2013a). This agency paradox needs to be overcome by institutional entrepreneurs, aiming at creating, maintaining, and disrupting institutions (Lawrence et al. 2009). They do this by influencing public policy and legislation.

Microcredit is one example of a social innovation because it is an initiative taken by actors in order to provide new answers to social problems (social and financial exclusion, poverty) and a device capable of providing services to enable construction of a society with high levels of quality of life. Hence, it is also a social innovation (Assogba 2007; Couchoro 2001) in the sense of focus on being a response to social needs (Cloutier 2003). It may also impact the environment because it is focused on a local development. It has developed new social relations in different ways (Ashta et al. 2013) that have included getting conservative local actors to work towards inclusion (Marti and Mair 2009). However, there are a multitude of conservative actors who are nonlocal and would like to use the microcredit movement to suit their own ends instead of developing entrepreneurship. We therefore need to provide other solutions to mitigate the misuse of microcredit. One such solution is to provide other financial products and go from microcredit to microfinance. In this paper, we focus on microfinance and whether the new financial products can develop entrepreneurship.

Microfinance is the provision of financial services to the poor and the financially excluded. These financial services include credit, savings, insurance, remittances, and guarantees, among others. As a result, an associated vocabulary includes microcredit, microsavings, microinsurance, microremittances, and microguarantees. A relatively new focus has been on providing microequity.

The major common problem of providing all these services to the poor is that the transaction size is very small. As a result, any processing cost, or transaction cost, becomes a high percentage of the transaction amount. This makes the product very expensive for commercial banks and formal financial institutions to provide these services to the poor, who therefore remain excluded. A second common problem is that the poor not only lack financial capital but are also often socially excluded and lack bridges to rich people. A third common problem is that they are often uneducated, even illiterate, and excluded from technological innovations.

To solve these problems, microfinance institutions (MFIs) have created social innovations which permit them to offer financial products which were otherwise not viable commercially (Armendàriz and Morduch 2010). Seeing the success of MFIs, hitherto conservative commercial financial institutions are also downscaling to profit from the vast market at the bottom of the pyramid. All of these are trying to use advanced technologies such as management information systems, mobile banking, and online financing to increase their outreach (Ashta et al. 2011). The question is whether their own 
ideological heritage will permit conservative institutions to foster entrepreneurship or to turn the system to their advantage.

\section{Research methodology}

Our research methodology is to use literature reviews and descriptive research based on empirical data from secondary sources. Such research is a good starting point to take inventory as well as to find patterns based on which future analytical research can find explanations.

Descriptive research on industry dynamics has identified a dominant pattern where prices fall, output rises, and the number of firms rises and then falls over time. Several models have been advanced to explain these patterns (Lenox et al. 2007).

The descriptive research on compliance costs emphasizes the burden of compliance costs, with little attention to measuring any benefits from tax planning. In contrast, the analytical research in tax evasion suggests an incremental benefit of compliance costs in reducing taxes (Mills 1996).

In fact, there is a growing field which considers that too many papers unnecessarily develop theoretical models rather than simply presenting their findings (Leung 2011; Hambrick 2007).

\section{Results and discussion}

We will start with the relationship of entrepreneurship to microcredit because it is the most developed product in microfinance. But today, it is being increasingly realized that other complimentary financial products are necessary for the poor, and the relationship of these to entrepreneurship will be discussed in the next part.

\section{Microcredit and entrepreneurship}

\section{What is microcredit?}

In underdeveloped countries, the vast majority of the population has no access to the banking system, whether in rural or in urban areas. The absence of appropriate formal financial services had long led the people to the informal financial sector. At best, they use Rotating Savings and Credit Associations (ROSCAs), a traditional practice of mobilizing savings, brilliant but sometimes very risky (and reserved for the middle class, the one having the capacity to save) and at worst they are entrenched with the usurious moneylender, with very prohibitive interest rates, for example, 300\% in Ethiopia (Belwal et al. 2012). In the 1990s, it was estimated that $90 \%$ of adult African population was excluded from financial services compared to $85 \%$ for Brazil (Gentil and Servet 2002). Data available from Microcredit Summit shows that by 2010, $11 \%$ of the poor in Africa and Middle East, 32\% in Latin America, and 69\% in Asia and the Pacific were being covered by microcredit (Maes and Reed 2012). To the extent that a dent has been made in the exclusion problem, we can say that in this respect (outcome), microcredit is a social innovation.

To understand the other aspects of this social innovation, it is important to understand the problems it addressed. Essentially, lending to the poor suffered from three 
major problems: default risk, transaction costs, and lack of complementary inputs (Armendàriz and Morduch 2005; Ashta 2009; Wydick 2002). The first, default risk, arose from asymmetric information as well as a lack of physical collateral with the poor borrowers. The asymmetric problem arose from the lack of information on the borrower's ability and willingness to repay the loans and thus an inability to separate safe borrowers from risky types. The lack of enforcement capacity owing to voids in legal enforcement systems created other threats for reinforcing moral hazard. The second, high transaction costs, arose from the small, or micro, size of the loan being attributed. Any fixed cost of processing the loan application as well as servicing the loan to take back reimbursement becomes high in relation to the small amount of the loan. Finally, even if the poor could be provided financial capital, it was felt that they would not be able to be entrepreneurial since they did not have the necessary complimentary social and human capital. This reinforced the moral hazard. For richer borrowers, banks solve the risk problem by asking for collateral, but the poor do not have either collateral or the legal documents for the property they may have acquired (Belwal et al. 2012; De Soto 2000).

Microcredit aims towards a minimal equality in the access to credit by allowing people excluded from the traditional financial system to take loans for creating their own jobs. It can be defined as any loan initiative intended to create income-generating activities, focused on microentrepreneurs with no access to traditional bank lending. It aims to fight against poverty. The Microfinance Information eXchange (MIX) 2010 statistics show that gross loans portfolio and the average loan are different from one region to another (Table 1).

Owing to low transaction sizes and because of the relatively high processing costs, MFIs apply an interest rate generally higher than that of the banking sector. Regulators do try in some countries to control this, but the ceiling varies over time. For example, in the particular case of countries of the West African Monetary Zone (Couchoro 2011), laws on usury for all financial institutions operating in the area impose 'an usury ceiling' not exceeding twice the discount rate of the central bank (i.e., 17\% per year). The MFIs have since obtained a waiver; the central bank has revised the law on usury. Today there are two ceilings: one for commercial banks (18\%) and the other for MFIs (27\%). Therefore, we can see that microcredit has been able to influence public policy to enhance its institutional work.

\section{Evolution of microcredit}

Microcredit is a new form of lending to the poor, hailed as a social innovation of the 1970s, resulting in loans to about 200 million people (Maes and Reed 2012; Reed 2013) and impacting about a billion people (taking a family size of five). Figure 1 illustrates

Table 1 Microcredit institutions' loan statistics

\begin{tabular}{lcc}
\hline Regions & Gross loan portfolio (US\$) & Average loan size (US\$) \\
\hline Africa & 4.6 billion & 371.9 \\
Latin America and the Caribbean & 22.9 billion & $1,024.4$ \\
South Asia & 8.4 billion & 144.0 \\
East Asia and Pacific & 21.2 billion & 305.6 \\
Eastern Europe and Central Asia & 8.3 billion & $1,687.8$ \\
\hline
\end{tabular}

Source: The Microfinance Information eXchange (MIX) 2010. 


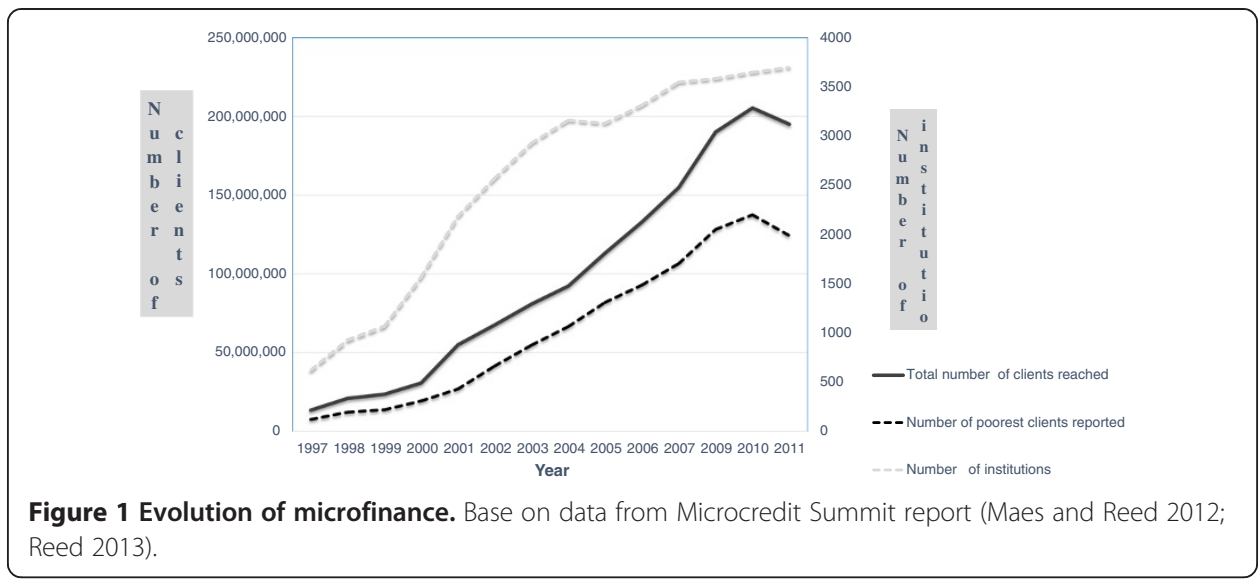

the evolution of microcredit: the top curve uses the secondary axis and indicates that today, 3,703 MFIs report to the Microcredit Summit Conference, indicating that they have reached 195 million clients out of which 124 million are very poor.

Microcredit is staged today as a global movement and part of a globalization process, and is considered as an excellent indicator of economic, social, and cultural opportunities, 'an important lever for change, contributing to local development ...' (Gentil and Servet 2002).

The number of customers has more than doubled from 2003 to 2011 (Table 2). Table 3 provides the geographical distribution of microfinance.

\section{Microcredit model}

Microcredit consists generally of short-term loans with repayments that occur as soon as the loan is disbursed. Repayment is either weekly or monthly.

The social innovation that microcredit was typically associated with was the use of an innovative mechanism in the financial world in order to reduce default risk and to avoid excluding candidates to credit: creating groups of borrowers for lending to the poor, staggered lending, progressive lending, frequent repayments, local management, compulsory savings, and training in the management of income-generating activities. While these methodologies are often associated with the Nobel Peace Prize winning Grameen Bank of Bangladesh, similar models started at around the same time in Brazil and Bolivia and even existed decades earlier in the informal sector, such as tontines or Rotating Savings and Credit Associations. Professor Muhammad Yunus, the founder of Grameen Bank, was able to create a faster social diffusion of his particular, and this helped him get, conjointly with his bank, the Nobel Prize. In this group lending model, money is lent first to two women in a group of five, and they are told that another two

Table 2 Number of people served by microcredit

\begin{tabular}{lccccc}
\hline & $\begin{array}{c}\text { Minimum } \\
\text { number of MFIs } \\
\text { reporting }\end{array}$ & $\begin{array}{c}\text { Customers } \\
\text { served } \\
\text { (millions) }\end{array}$ & $\begin{array}{c}\text { Number of } \\
\text { poorest in first } \\
\text { loan (millions) }\end{array}$ & $\begin{array}{c}\text { Numbers of women } \\
\text { among the poorest } \\
\text { (millions) }\end{array}$ & $\begin{array}{c}\text { Percentage of } \\
\text { women among } \\
\text { the poorest }\end{array}$ \\
\hline 31 December 2003 & 2,931 & 81 & 55 & 45 & 82.5 \\
31 December 2009 & 3,589 & 190 & 128 & 105 & 81.7 \\
31 December 2010 & 3,652 & 205 & 138 & 113 & 81.9 \\
31 December 2011 & 3,703 & 195 & 124 & & \\
\hline
\end{tabular}

Source: State of the Microcredit Summit Campaign Report 2004, 2011, and 2012 (Daley-Harris 2004, 2011; Maes and Reed 2012; Reed 2013). 
Table 3 Number of active borrowers of microcredit

\begin{tabular}{lcc}
\hline & Number of microcredit institutions & Actives borrowers (millions) \\
\hline Regions & 1,009 & 12.7 \\
Sub-Saharan Africa & 1,746 & 169.1 \\
Asia and the Pacific & 647 & 13.8 \\
Latin America and the Caribbean & 91 & 4.3 \\
Middle East and North Africa & 73 & 5.2 \\
Eastern Europe and Central Asia & 86 & 0.2 \\
North America and Western Europe & 3,652 & 205.3 \\
\hline Total & $2012($ Mas and
\end{tabular}

Source: State of the Microcredit Summit Campaign Report 2012 (Maes and Reed 2012).

will get a loan only if the first two repay. Thereafter, if all four repay, the fifth would also get a loan. This simple mechanism coupled with some others overcame some of the problems outlined above. The use of social information available to the groups helps them seek similar kinds of members (safer ones) to overcome adverse selection. Constant monitoring of each other as well as pressure to repay helps them overcome moral hazard. The group would also provide help (advice, network) to each other so that the other members succeed and others would get a loan. The group lending consists also of granting credit to a group whose members are chosen freely and are jointly or severally liable for the repayment of all the loans to the group. If one member fails, the others are required to force her to honor the commitment, otherwise they will be the ones who will pay back in her place. Reimbursements were also more likely if the loans were collected frequently: weekly rather than quarterly. The joint liability of the group enabled social collateral to fill the absence of physical collateral. To reduce transaction costs, repayments were made by all the groups of the village at the same time, enabling the credit agent to come to a village, take the money, and then proceed to the next village. Often, loans were made to women since they were considered safer to lend to. An ancillary benefit has been the empowerment of women if this has led to them participating in society. Lending is most of the time progressive and consists of providing credit in tranches whose amount increases as the reimbursement is effective. Future loans are provided only if the previous period has been repaid.

Microcredit has been confronted with many problems and has responded by innovating: providing individual credit (once the group-based lending has permitted information gathering), nonstandard sums, providing credit to men also, and many other innovations. Moreover, since credit is only one financial service and produces stress, new innovations included the development of microsavings, microinsurance, microguarantees, microremittances, and micropayments. All of these have fueled the growth of microfinance.

The rapid growth of the microfinance sector has been accompanied by high profitability for a vast percentage of MFIs. Based on voluntarily submitted data from Microfinance Information eXchange by over 1,000 MFIs, we find that the median return on equity (ROE) is $8 \%$, and from Figure 2, we can see that a good three-fourths (below the top curve) is profitable (ROE > 0), about half have a ROE greater than $10 \%$ (between the top two curves), and about one-tenth of all MFIs manage to obtain a return on equity higher than $40 \%$ (below the bottom curve). 


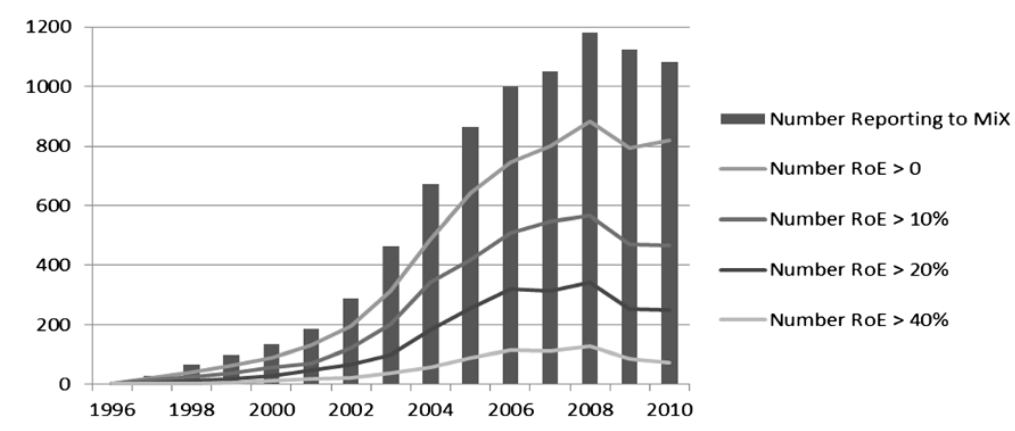

Figure 2 Return on equity of microfinance institutions. Based on MIX data downloaded on June 12, 2012.

How is lending to the poor so profitable? Part of the answer lies in high interest rates charged to offset high operating costs. Using yield as a proxy for interest rate, according to our data from the MIX, the median MFI charges $28 \%$ per annum, as shown in Figure 3, about one-fourth charge more than $40 \%$ per year, and about a tenth of MFIs charge more than $60 \%$ per year. A few outliers charge more than $80 \%$, yielding to a lot of public and academic debate on the ethics of MFIs (Ashta and Bush 2009; Rhyne and Guimon 2007; Rosenberg 2007). At the same time, these interest rates are much lower than those of moneylenders (Eversole 2003; Armendàriz and Morduch 2005).

It is believed that interest rates in microfinance will reduce only with a reduction in operational costs owing either to competition-induced better governance (Rosenberg et al. 2009) or due to the use of innovative technologies such as cloud computing information systems, mobile banking, and online financing of microfinance institutions (Ashta 2011). Together with these technological innovations, it is believed that institutional innovations are required in public governance as well as corporate governance.

Despite this impressive growth, it is recognized that only $11 \%$ of African poor have access to microcredit, and large tracts of Latin America are also not covered (Maes and Reed 2012). According to Epstein and Yuthas (2010), it is possible that MFIs avoid areas where they believe that there are either cultures of non-repayment or because the poor lack the necessary entrepreneurial abilities. These cultures of non-repayment may be owing to factors such as individualistic (as opposed to collectivist) characteristics, attitudes towards the debt and the wealthy, and mistrust of institutions and prior

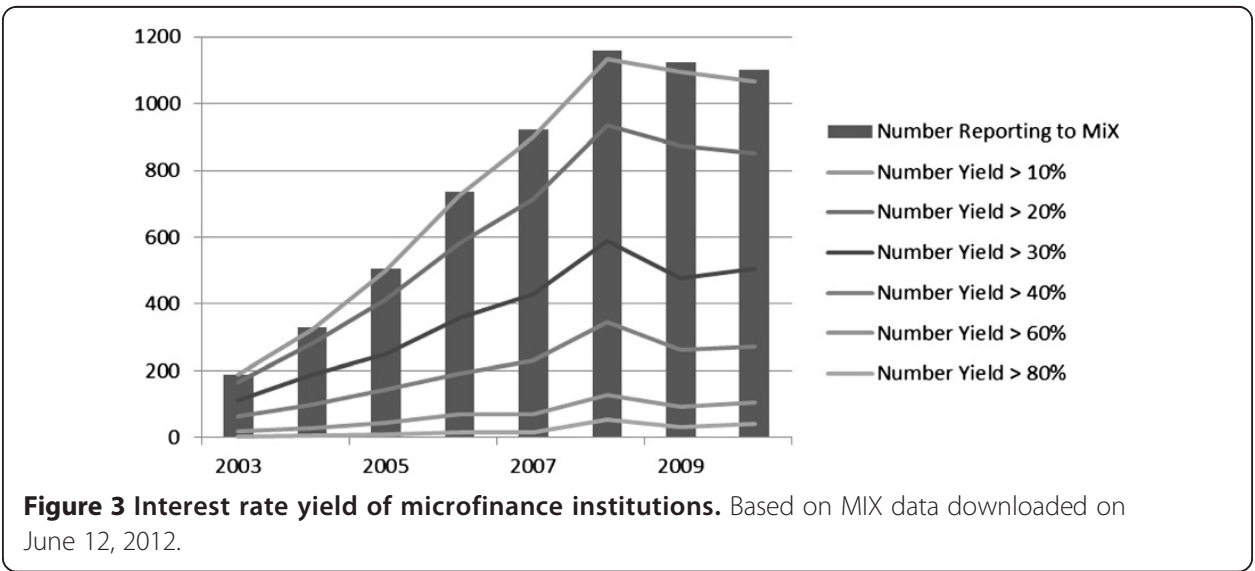


governmental and nongovernmental organization (NGO) interventions involving debt forgiveness. They suggest the use of smaller groups and strengthening ties between members by encouraging them to help each other's business, thus building trust between the members, and a more personalized and closer interaction between the MFIs and the borrowers with business and capacity building activities and transparency to build trust with the MFI, thus distinguishing it from other institutions with whom the borrower may have dealt in the past.

\section{Microcredit and entrepreneurial opportunities}

Microcredit is believed to finance survival enterprises rather than entrepreneurial enterprises which are larger and better capitalized (Epstein and Yuthas 2010). Development actors want to show the potential of poor people to take entrepreneurial initiatives. Through microcredit, they want to highlight the ability of the poor to create their own business, doing their own jobs, if they are freed from the constraint of self-financing their projects. Microcredit is for the masses excluded from the conventional financial system, sometimes subject to the whims of suppliers and the dependence on moneylenders, with a hope to enable them to develop a wide range of productive activities, thus generating income, and in turn, improve their living conditions and social status.

Microcredit is characterized by a strategy based primarily on a participatory process. This process requires the active involvement of all actors in society, especially the borrowers, towards the objectives of fighting against poverty. Through this approach, the poor will find the opportunity to influence policies that are supposed to affect their lives. The philosophy of microcredit is that the beneficiaries should not be passive actors in the fight against poverty (which makes them assisted), but rather active actors, responsible for improving their living conditions. Undoubtedly, it has the characteristics of participation and empowerment that are radically different from assistantship.

However, the scope of microcredit is limited to the ability of beneficiaries to enhance the resources that are available to them. Microcredit should not give the impression that everyone is able to create, edit, manage, and develop her own business.

\section{An evaluation of microcredit for entrepreneurship}

An interesting framework for the evaluation of microcredit was provided by Zeller and Meyer (2002) who argue that successful microfinance institutions have to balance the triangle of outreach, sustainability, and impact. Outreach is often divided into breadth (number of poor people reached) and depth (vulnerability of poor people reached). As we can see, the triangle is essentially consisting of problems inherent in any double bottom line or hybrid entity: how to balance the need for high breadth of outreach and economic profitability with the need to reach the most vulnerable and have an impact in getting them out of poverty by helping them develop their enterprises.

In recent years, microcredit has come under increasing attacks from virulent academics and media. These critiques can be grouped into two major categories: the first one is mission drift and the second one is related to its lack of proven impact. We will discuss both of these as they relate to entrepreneurship. 


\section{The mission drift}

The mission drift critiques are usually on diversion into consumer credit, larger loan sizes, and high interest rates. Thus, according to them, microfinance starts to resemble the existing conservative actors (banks, consumer finance, moneylenders) who perpetuate poverty by redirecting microfinance from entrepreneurship which would solve the poverty problem. The first critique of mission drift is essentially that microcredit is increasingly being used for consumer credit rather than entrepreneurial finance. This is not to say that consumer credit is bad: it may lead to positive outcomes such as consumption smoothening, food consumption, economic self-sufficiency, and some aspects of mental health and outlook, with some finding negative effects on other aspects of mental health (depression and stress) (Karlan and Zinman 2010). And of course, the dividing line between consumer finance and entrepreneurial finance is often blurred: for example, how would you place education loans or loans for professional training? An innovative method for combining education and microfinance is provided by Tooley (2007) who suggests that private education-dispensing enterprises should be formed (since public schools do not deliver) and financed by microloans.

A second critique is that even when it is being used for entrepreneurial finance, we are using it for giving loans to the near poor rather than the poorest. For example, Copestake et al. (2001) studied PULSE in Zambia and found that it targets clients who are better off than the poor. This is usually reflected in larger loan sizes. Larger loan sizes are usually applied for by those who are educated, males, those with access to bank credit, and those having assets for collateral; and MFIs grant larger loans at higher interest rates to those who have more assets, higher valued collaterals, minimal equity, effective loans, and more experience (Dutta and Magableh 2006). Often, it is not possible to expect the ultra-poor to become entrepreneurs without first giving them subsidies aimed at building their minimal capacity to enterprise (Tavanti 2013). The critique needs to be nuanced in the wake of the Microcredit Summit data indicating that 124 million of the 195 million microcredits are in fact going to the very poor. Another part of this critique is that the institutions posing as MFIs are actually financing small enterprises managed by not-at-all-poor entrepreneurs (Pisani and Yoskowitz 2004).

A third critique is that profitability motivation has led to a focus on high interest rates which siphon off the profits from the microentrepreneur to the microfinance institution, creating a feeling of deceit among the borrowers (Eversole 2003). A wave of critiques in the media and in academics took off with the successful IPO in 2007 of the microfinance MFI Compartamos which was reported charging interest rates as high as 99\% per year (including VAT) (Ashta and Bush 2009; Ashta and Hudon 2012; Lewis 2008; Smith and Epstein 2007). A second much publicized IPO that attracted critiques was by SKS in 2010 in India which led to accusations that the microcredit is causing borrower stress and even suicides (Ashta et al. 2011). This led to the collapse of microfinance in Andhra Pradesh in India. The size of this state's microfinance is so important that it may largely explain the reduction in global microfinance from 205 million clients to 195 million clients (Reed 2013).

\section{The impact of microcredit}

Studies on the impact of microcredit have shown mixed results. Some show positive impact on enterprise, households as well as the community (Woller 2002; Pitt et al. 2006), 
while others show no impact or mixed results. For example, Wydick (2002) finds some initial positive impact on enterprise growth in terms of revenue and employment generation from taking microcredit but stagnation in the number of employees thereafter, and those women entrepreneurs taking microcredit gain more than male entrepreneurs in terms of staying in the program as well as employment generation. Afrin et al. (2010) find that the positive impacts on successful women entrepreneurs come from microfinance institutions providing them complimentary human and human capital by teaching them financial skills and providing them a group identity. The financial skills could also have been imparted to the families of women if they were in business. Belwal et al. (2012) find that income and savings of women entrepreneurs increased after taking microcredit, but they conclude that this did not have any positive impact on their lives after loan repayment and interest. Studies on the lack of impact of microcredit focus usually on either statistical results or reasons of overfocusing on microcredit to deliver anything.

The first group consist of experimental as well as qualitative studies indicating that microcredit has no impact, no statistically significant positive impact, or that any impact which is proven is not robust from one study to another or on one indicator across geographies. For example, one study indicates that those entrepreneurs who take a second loan have usually gained in terms of profits, household income, and diversification, but those who drop out after one loan have usually suffered (Copestake et al. 2001).

The second group of studies focuses on the impossibility of credit alone to alleviate poverty. They usually focus either on the need for providing complementary capital to financial capital or on financial services other than microcredit. For example, Gomez and Santor (2001) show that the success of microfinanced enterprises is significantly determined by social capital of the entrepreneur and the neighborhood environment. Similarly, Burand (2012) would like to complement microcredit with ready-to-go microfranchise packets of desirable goods that the poor can market in their villages and communities through networks. Thus, we see the importance of social capital in marketing the products financed by microcredit, as well as the human capital of the people who designed the microfranchise packet.

\section{Other microfinance products and entrepreneurship}

To overcome the criticisms of microcredit, which could be viewed as conservative actors taking over the work of social innovators and institutional entrepreneurs to suit their own ends, it is evident that new avenues need to be explored. One response has been to indicate that for microcredit to be useful, the poor need a range of other financial products. Social entrepreneurs are therefore trying to provide these additional financial services. Evidently, if ways of diffusing other financial products to the masses can be found through social innovation, then conservative actors too could take over these innovations to suit their own ends. These new financial products include guarantees, insurance, savings remittances, and equity, as shown in Figure 4. In this part, we look at the relatively smaller literature on these aspects to see if these financial products would foster entrepreneurship and, through this, an end to poverty or whether it would merely impact consumption.

\section{Microguarantees and entrepreneurship}

Evidently, if microcredit is placing stress on microentrepreneurs, it is because MFIs do not guarantee their returns and they themselves are under pressure. This is evident as 


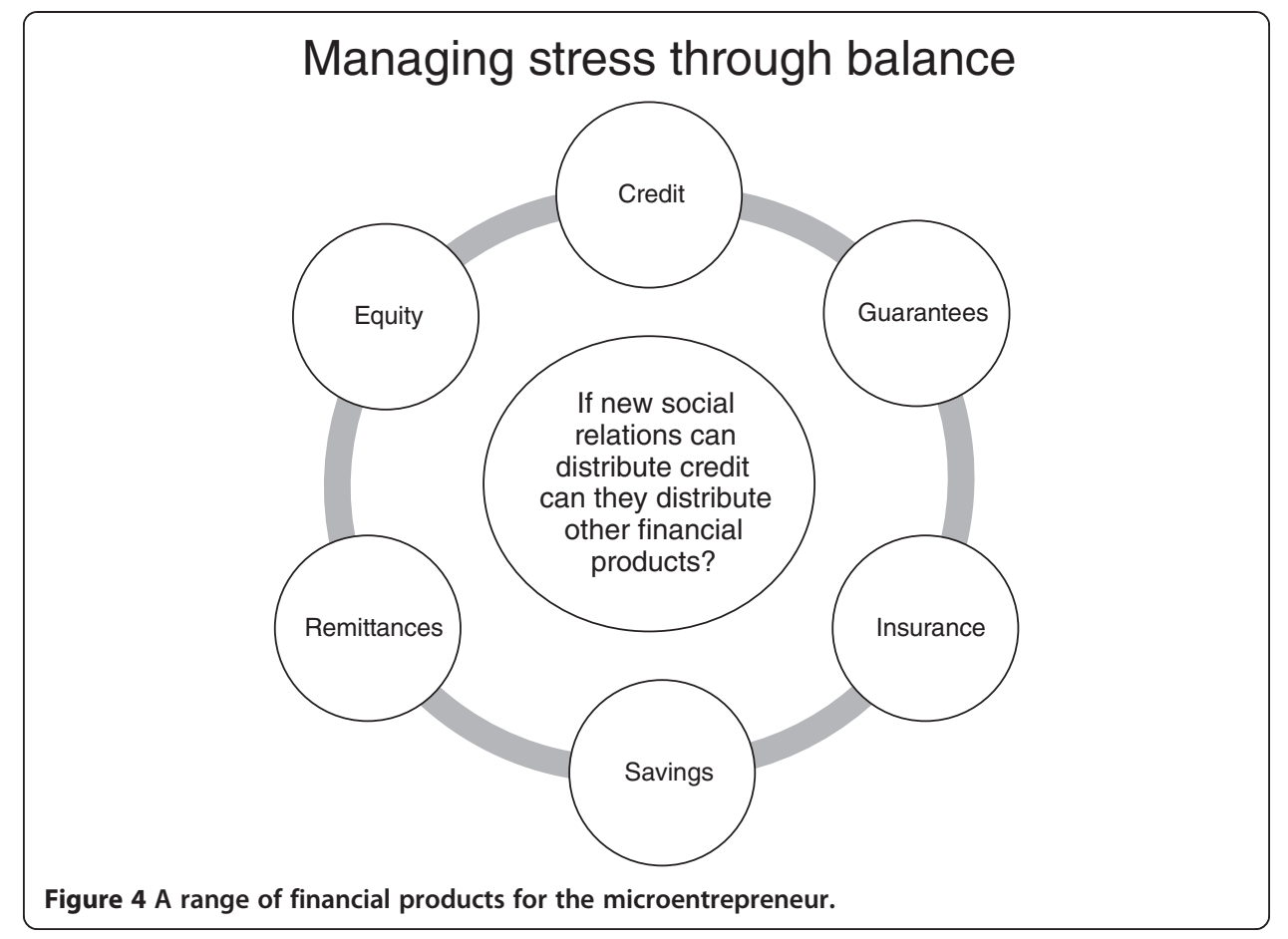

the business model moves from group credit, with its inherent social guarantees, to individual lending. Thus, individual guarantees would be the first solution to the new social problem of stress in the system.

In developed countries, mutual guarantee associations or government-backed public institutions guarantee part of the banks' loans to entrepreneurs (De Gobbi 2003). This reassures the bank because often entrepreneurs are able to pay back a large part of the loan, even if they are not successful in total reimbursement. The European Association of Mutual Guarantee Societies has 34 members providing guarantees for 1.9 million small and medium enterprises (Source aecm.org 2009 statistics). This is the case for example in France of the social cohesion fund, established by the Planning Act for Social Cohesion on 18 January 2005 (Lecomte 2008). The fund has over 5 years of 73 million euros. It brings guarantee for microenterprises created by disadvantaged populations or individuals who are victims of banking exclusion. However, although such guaranteeing institutions are cropping up in developing countries, they do not have the required outreach among the poor.

Guarantees are closely related to microcredit. Part of the reason microentrepreneurs, especially poor ones, are not able to get loans is that they do not have collateral. Microfinance has used social solidarity guarantees to overcome this problem: if one of the borrowers cannot pay, someone else from the group would not get a loan or someone else from the group must pay (De Gobbi 2003).

Of course, microentrepreneurs can also get guarantees from people who do have collateral. But very often, poor people lack the bridging social capital to meet richer people who would be willing to put their assets at risk for helping out the poor. Today, thanks to technology, we see the development of websites such as UnitedProsperity.org which take cash from someone in a rich country which then serves as cash collateral for a 
bank loan to a MFI and from the MFI to a poor entrepreneur, thus extending the ability of the MFI to give loans to poor people.

\section{Microinsurance and entrepreneurship}

The difficulty in mobilizing guarantees from rich people in favor of microentrepreneurs led to a search for insurance to cover the risk of default. As it became evident that business default came not only from business risk but also from personal risks of the microentrepreneur not being able to work, for example for health reasons, personal microinsurance was also desired. Insurance for the poor as mutual protection was the foundation of many insurance countries in the nineteenth century (Churchill 2007). The importance of microinsurance emanates from the limitations of conventional loanbased microcredit programs in protecting the poor from all sorts of vulnerabilities. Although microcredit has been shown to generate various beneficial outcomes, there is also evidence that not all sectors of the poor can benefit. One such group is those who experience severe health shocks, which reduce work capacity and investment and require a redirection of resources to the consumption of healthcare (Hamid et al. 2011). Due to increased evidence that microcredit does not help the poorest of the poor, welfarists stress the value of adding auxiliary services to improve the effectiveness of the programs (Hamid et al. 2011; Bhatt and Tang 2001; Woller et al. 1999; Woller and Woodworth 2001). Insurance can protect vulnerable people from risks and shocks when existing coping strategies fail.

The first noted search for microinsurance is a paper by Dror and Jacquier (1999). A notable publication is an edited publication by Churchill (2006).

Microinsurance is a program which provides insurance services to low-income populations and small businesses in developing countries. It is typically characterized as a financial arrangement to protect low-income people against specific perils in exchange for regular premium payments proportionate to the likelihood and cost of the risk involved (Biener and Eling 2011; Churchill 2007). As this definition implies, microinsurance serves the low-income population based on the same fundamentals as regular insurance (Biener and Eling 2011). A wide range of risks is covered, and products comparable to those in regular insurance markets are provided. Common types of risks covered are life, health, disability, and property (especially agricultural insurance). The particularity is that microinsurance is characterized by low premiums and low caps.

Most MFIs admit that many clients use loans to pay for medical expenses, funerals, or to smooth household cash flow. Even if they do not have an immediate emergency, some customers only invest a portion of the loan in their businesses and save the rest so that they will have a cushion to fall back on if they experience repayment problems (Churchill 2002). These assertions support the argument that in the absence of significant assets and other risk mitigation mechanisms, the poor lack the capacity to withstand the consequences of many shocks (Cohen et al. 2005). A study in Tanzania, Uganda, and Kenya shows that for the poor, the impact of a shock follows a two-step process: the immediate impact of the loss of assets and/or income and need of money, and the impact in the medium and long term that requires strategic choices coming from households, particularly in terms of resource reallocation (Barlet 2000). Thus, a shock that would prove mild to upper- and middle-income households can, in the case of a poor household, dramatically reduce assets (including stocks of physical and 
human capital), reduce or eliminate income sources, lead to reduced consumption, and ultimately put present and future generations of the poor deeper into poverty. The vulnerability is directly related to the ability of households to manage risk (Barlet 2000). To cope with shocks, poor households use many different risk management strategies, including informal group-based and self-insurance mechanisms, such as borrowing, saving, and drawing down productive and nonproductive assets. A relatively new option for the working poor to manage risk is microinsurance. Indeed, for a low-income person, usually the beneficiaries of microcredit for the implementation of microprojects, microinsurance paves the way for better risk management and helps reduce vulnerabilities to shocks.

The poor are more vulnerable to risks than the rest of the population (Churchill 2007), and they are the least able to cope in case of occurrence of the crisis. Furthermore, poverty and vulnerability reinforce each other in an escalating downward spiral. The occurrence of a crisis puts particularly financial pressure on low-income persons who, moreover, suffer from the uncertainty about whether and when a loss might occur. Because of the precarious world of the poor, a shock such as illness, death of a loved one, fire, or theft can rapidly erase hard-won gains and make the escape from poverty harder to achieve (Cohen and Sebstad 2005). Based on this apprehension, the poor are less likely to take advantage of income-generating opportunities that might reduce poverty (Churchill 2007). The link between vulnerability and entrepreneurship is no longer subject to doubt. A shock plunges a person or a low-income household in a state of inactivity and therefore in poverty by the loss of labor force or by massive absorption of household resources.

Microinsurance may be either directly related to entrepreneurship or indirectly related. Examples of direct relationship with entrepreneurship include property risks such as crop insurance, cattle/livestock insurance, theft/fire insurance, and insurance for natural disasters. The reasoning is that when a farmer has insurance against downside risk, he is inclined to be more risk seeking which can pull him out of poverty. For example, if he is insured against crop failure, he can use innovative cropping strategies which may have higher yields.

Examples of indirect relationship with entrepreneurship include health and accident insurance (illness, injury, disabilities). Often, if a poor entrepreneur falls ill, he is unable to work and repay loans. As a result, his business collapses. If health insurance kicks in, he is able to survive during this critical period and continue repaying his loans. Research suggests that households that are insured against hospitalization and accidental death have less diversified income portfolios (Kwon 2010). This focus on a core business may improve profits.

No centralized agency maintains public-access documents for microinsurance. A survey in Africa (Matul et al. 2009) estimated that there were 14.7 million poor people insured in Africa, $56 \%$ of which is in South Africa. The most used insurance product was credit life insurance, i.e., an insurance which repays the debt if the insured dies.

Microinsurance may be delivered directly by insurance companies but is often packaged in ways by which it can be delivered by microfinance institutions, which are directly in contact with microborrowers. Some microinsurance programs are community-based mutualization of risk but suffer from low coverage. Two preconditions for commercial microinsurance firms to successfully sell directly to the poor is to understand how the 
poor are different and have different needs and to educate the poor on the use of insurance (Churchill 2007).

A study of 600 MFIs indicated that MFIs' willingness to offer microinsurance is positively correlated to a rise in the financial expense ratio, loan repayments in arrears, years of operation, number of borrowers, woman borrower ratio, life insurance penetration ratio, and family size. In contrast, the willingness to offer microinsurance is negatively correlated with their loan asset ratio, bad loan write-off ratio or average loan size in comparison to GNI per capita (Kwon 2010).

In conclusion, improved health status may lead to higher productivity, higher labor supply, fewer workdays lost, and reduced healthcare expenditure (Hamid et al. 2011). In addition, if households are insured against health risk, they may invest in highreturn riskier assets because they do not need to retain cash or to hold highly liquid assets for precautionary purposes. Microinsurance is therefore an innovation for fostering entrepreneurship.

\section{Microsavings and entrepreneurship}

One problem with insurance is that the microentrepreneur has to pay premiums, which he may not be able to afford, especially if the risk is shared only by local entrepreneurs. A cheaper alternative would be for the entrepreneurs to save money and use it when required. Savings can be useful for transactional reasons (consumption smoothening), precautionary reasons (risk mitigation) as well as speculative reasons (windfalls/opportunities). 'Saving is where financial services begin and end' (Rutherford 2001). Microsavings are the small amounts of money saved by poor people with financial institutions, mostly MFIs. They provide a source of lump sum cash in case of future events, i.e., emergencies, start-up business capital, and major life cycle events, and they support daily consumption needs of the poor people (Mersland and Eggen 2007).

MFIs have the development objective of employment creation to facilitate growth of enterprises along with poverty reduction. As financial service providers, MFIs on one hand provide loans to accelerate growth of existing enterprises and facilitate creation of new enterprises while, on the other hand, gives the entrepreneurs access to secure places for savings. With majority of the MFI clients being women, researchers inferred that credit and saving services have contributed partially towards incomes and savings of women entrepreneurs (Belwal et al. 2012). Among the poorest of the poor, the most important element of microfinance is not lending but providing savings opportunities (Collins et al. 2010). Such savings can be quite useful in the lives of the poor people as once a large amount is accumulated together, this can finance acquisition of assets, construction of houses, and more importantly, starting up community-based enterprises.

Rutherford (1999) describes three basic ways people can covert a flow of savings into a lump sum: 'saving up', 'saving down', and 'saving through'. Saving up is mentioned as the small accumulation of money until it reaches a lump sum; saving down refers to loans, where people save in the form of making the repayments of the loans; and saving through is either through insurance or some other group-based system where the poor people may get access to a lump sum at the time it is needed through a series of small savings. All three systems are important to promote entrepreneurial activities as financing the entrepreneurship needs of poor clients is on top of the list of financial service-providing MFIs, and this smoothens the client's income, thus helping build a sustainable livelihood (Tavanti 2010). 
Empirical evidence also suggests that poor people use saving products more than they use credit. The Opportunity International Bank of Malawi has 45,000 borrowers and 250,000 savers, the Equity Bank in Kenya has 715,000 borrowers and four million depositors, and the Grameen Bank has over US\$1.4 billion in deposits, which is 145\% of its outstanding loan portfolio of US\$965 million (Maes and Reed 2012). In a study in Bangladesh, it is found that there are 27.8 million depositors and about 20.6 million borrowers in a sample of 28 MFIs and that 26 of these 28 Bangladeshi MFIs have more depositors than borrowers (Khan and Ashta 2012). Another study has shown that only $24.5 \%$ of the services of the microfinance institutions go towards the extremely poor (Rahman 1998). Extremely poor people generally tend to exclude themselves from traditional microcredit programs, either through self-exclusion or through a process of peer screening. Self-exclusion refers to the poor people's fear of not being able to repay the loans due to different social and/or religious barriers; thus, they are not willing to borrow (Hashemi 1997). Many of the poor people are also excluded by the peer members of the traditional group methodology, where they are regarded as risky and unreliable as social collateral (Hulme and Mosley 1997). While the poor people do have their own ways of coping with vulnerability, they do so by accessing savings schemes and emergency loans to enable themselves to cover short-term crises (Hasan and Iglebaek 2004). In this process, they develop a social relationship with the microfinance institutions, where they demand to be served individually through carefully designed savings products. SafeSave in Bangladesh has demonstrated such relationship with its clients through the introduction of a daily collection system and service delivery at the doorstep of the clients. The basic philosophy of SafeSave's financial service to its clients is to give them the opportunity to save, without any mandatory requirement to borrow, unlike the traditional Grameen approach, where progressive borrowing is a precondition to access such service.

However, there are many informal sector microsavings institutions on which very litthe data is available. For example in Ethiopia, there are community-based organizations such as Ekub, a system of forced saving, with finance secured through traders, friends, and relatives; and Iddir, informal associations where members save for funeral costs (Belwal et al. 2012). Similarly, there are susu schemes in West Africa (Adusei and Appiah 2012). In addition, there are microfinance institutions which may require compulsory deposits as a prerequisite to providing loans.

Adusei and Appiah (2012) studied the impact of the susu scheme on entrepreneurs. Essentially, these schemes collect a small amount of savings on a daily or weekly basis and return the money at the end of the month after taking a fee. During the period, the collected sum can also be lent out with interest, but no interest is paid on the deposits. These savings then help the entrepreneur discharge his end-of-the month working capital responsibilities. Ninety-six percent of the depositors find that the susu system helps them in their business. The perceived impact of this system of microsavings on business is more for married entrepreneurs as well as for male entrepreneurs, suggesting that women use their money for their families. Moreover, the impact on business is higher the longer the people stay in the system and the more they deposit.

Entrepreneurship can generate a much stronger concentration of wealth (Quadrini 2009). In many developing countries, among many economically active poor people, technical knowledge and skills are limited, as are money management skills and access 
to capital. Because of financial constraints, entrepreneurial investment depends on wealth. From this, the incentive of entrepreneurs to accumulate wealth to overcome the borrowing constraints is derived (Quadrini 2009). The propensity to save and to form solidarity groups to facilitate access to microsavings, which also gives security of the small amount of money the entrepreneurial poor accumulate over time, and combined with money management skill delivery, access to small amounts of capital for investment, links to financial institutions, business skills training, and various life skill enhancements resulted in the rapid growth of small-scale enterprises both at rural and urban settings. Again, enterprising households can have significant concentration of wealth, which could result from the high savings rates of the entrepreneurs (Quadrini 1999). Gentry and Hubbard (2004) quantified that entrepreneurial households own a substantial share of household wealth and income, and this share increases throughout the wealth distribution and the income distribution.

At all stage of business development, capital pumped in by the entrepreneur plays a key role (Chamlee-Wright 2002). The main source of finance for microentrepreneurs is personal savings (Gunu 2010). Small traders largely depend on their own savings to provide for the start-up capital, and at a later stage, they try to access alternative sources of fund to expand the business. MFIs, ROSCAs, Accumulated Savings and Credit Associations (ASCAs), and many other informal mechanisms are present globally to facilitate such access to varying financial services. Another key area of funding is remittances from migrant workers accumulated as savings. This accumulated savings and the technical skills the returning migrants gather during their stay abroad may provide the basis for entrepreneurial activities, which contribute to the economic development of their country of origin (Lianos and Pseiridis 2009). After the Vietnam War, Asian immigrants have successfully established numerous small business enterprises in US communities with the help of having access to capital through informal financial market (ROSCAs) and business counseling services (Chotigeat et al. 1991).

Although microsavings can be developed by banks, in many countries (for example, India), social innovator actors in the form of NGOs are not allowed to collect savings as this was reserved for banks. Now, in the wake of the Andhra Pradesh crisis, it is recognized that microfinance institutions need savings, and very small savings are being allowed by the central bank in the name of encouraging thrift. Thus, public policy is being used to permit social actors to get local finance to provide credit.

\section{Microremittances and entrepreneurship}

If the microentrepreneur has difficulty saving his own money, his next step for funding would be to turn towards love money from friends and family. This transfer or remittances often comes from relatives who have migrated. Human beings have migrated since the beginning of civilization. People migrate for food and security, searching better employment opportunities and income security. Today, migration does not take place only to change the destiny of migrating people but also to improve the livelihood conditions of families staying back in their home countries. This is done through remittances, which channel the migrants' income. Even when the migrants return to their home country, they bring in with them the benefits related to the skills acquired abroad and to the savings brought home by returnees with the purpose of undertaking entrepreneurial activities (Lianos and Pseiridis 2009). In 2005, the worldwide officially 
recorded remittances were US $\$ 232$ billion. Of this, developing countries received US $\$ 167$ billion, which was more than twice the level of development aid from all sources (World Bank 2006).

Remittance is the surplus portion of earnings sent back by the expatriate community from the country of employment to the home country. Over the years, remittance has emerged as an important source of external development finance (Hasan 2006). Remittance has significant impact at the household level. This impact of remittances partially depends on the characteristics of the migrants and the recipients, i.e., whether they constitute the rural poor or the more educated sectors of the population generally residing in urban areas (Hasan 2006).

The remittances from migrants are an important source of funding for the economies of developing countries and recipient populations. There are broad segments of society who would live in extreme poverty without these resources. It is considered that these transfers have a significant impact on poverty reduction, funding for housing, education, other basic needs, and even on investment and entrepreneurship. Woodruff and Zenteno (in Amuedo-Dorantes and Pozo (2006)) estimate that 27\% of microenterprises located in urban areas in Mexico rely on remittances from abroad.

In 2005, the worldwide officially recorded remittances were US\$232 billion. Of this, developing countries received US $\$ 167$ billion, which was more than twice the level of development aid from all sources (World Bank 2006). Total remittances have increased steadily and were US $\$ 440$ billion worldwide, and of this, US $\$ 325$ billion went to developing countries in 2010.

Even in a situation of economic and financial crisis in the migrants' country of residence, monetary flows tend to remain stable, unlike economic development assistance and investment. Remittances from migrants to their families in sub-Saharan Africa were US\$ 21.5 billion in 2010, despite a slight decline in 2009 due to the global financial crisis, according to the Migration and Remittances Factbook 2011 (Collection Statistics 2011 World Bank on migration and remittances). Of this, Nigeria received as much as US\$10 billion, followed by Sudan (US\$3.2 billion), Kenya (US\$1.8 billion), Senegal (US\$1.2 billion), South Africa (US\$1 billion), Uganda (US\$800 million), Lesotho (US\$500 million), Ethiopia (US\$387 million), Mali (US\$385 million), and Togo (US\$385 million). In terms of percentage of gross domestic product, the largest recipients in 2009 were Lesotho (25\% of GDP), Togo (10.3\%), Cape Verde (9.1\%), Guinea-Bissau (9.1\%), Senegal (9.1\%), Gambia (7.9\%), Liberia (6.2\%), Sudan (5.6\%), Nigeria (5.6\%), and Kenya (5.4\%).

It should be emphasized that the figures on which to base these reports do not include informal channels used by millions of migrants. These figures are therefore below the actual amounts. It is therefore essential to facilitate remittances and lower the transaction costs. It is estimated that sending funds to Africa costs on average $10 \%$ of the amount sent.

Remittances are cited as making up around $60 \%$ to $70 \%$ of recipient poor households' total income (De Bruyn and Kuddus 2005). Investment in health and education is valuable for long-term economic growth and poverty reduction. Studies have found that migrant families invested more in these areas (Murshid et al. 2002). While such investment works as an indirect contributor towards developing entrepreneurial skill, remittance acts as an enabler to develop human capital as well as direct investment in enterprise. Inflow of remittances is directly associated with a larger volume of own finance, which in turn affects the total financial size of the start-up project as well (Korosteleva and Mickiewicz 2011). 
The money sent by migrants to their families facilitates investment in both productive and consumption goods, which otherwise would not have been possible due the nature of large cash involvement in such initiatives (Yang 2008). Yang (2008) also identified that when developed countries facilitate employment opportunities for workers from overseas, this contributes in stimulating human capital investment and entrepreneurship at the household levels of developing countries.

Some key elements to promote entrepreneurship could be diverse source of capital, enabling environment, policy framework, and supportive infrastructure (Pages and Markley 2004). Running a profitable business also depends largely on the skill, capacity, knowledge, and training of the entrepreneur. Application of such knowledge and skill, often, could be facilitated through accumulation of large sum of money coming in the form of foreign remittance. While much of the incoming remittances are used by recipient household for consumption, any residual after consumption may be converted into savings to be used not only for future consumption but also for investment purposes (Rivera and Reyes 2011).

\section{Microequity and entrepreneurship}

Obviously a missing ingredient to microcredit, to provide relief to the over-indebted borrower, is equity. Therefore, we should immediately see the need for supplementing the equity of the borrower through founder's equity from savings, love money from remittances, and angel investors. However, very poor people have very little savings and their social network is often too poor to provide them with love money. It is evident that they need to go to business angels, but business angels are rarely interested in projects which are as tiny as a few hundred dollars or even a few thousand dollars.

There is therefore a need for microangels. This would be a new breed of investors who would provide small amounts of capital for different motivations. Some may want profit; some may want to do good to help poor people survive. We comment briefly on four such movements: the local investment movement in France (CIGALES), slow money, socially responsible investment and impact investment, and crowdfunding.

In France, since 1983, there are investment clubs such as CIGALES (Nouvel 2004; Taupin and Glemain 2006; Russo 2007) which regroup investors who want to make alternative use of their solidarity savings in local projects. At the end of 2012, the movement has grown to 220 clubs with almost 3,000 members (an average of 13 members per club). Thus, again we see the use of groups as a social innovation, made possible through the possibility of using a legal form (indivision) which is specific to France. The average contribution of each member is 25 euros a month or 300 euros a year. For 13 members, this makes a pooled investment possibility of 3,900 euros. This money is then invested in a microenterprise. While $95 \%$ of business angels are male, it is found that more than a third of these microangels are women, $72 \%$ have a university degree, and $72 \%$ are actively employed (Estapé-Dubreuil et al. 2012). The select projects are based on social and solidarity aspects, economic aspects, as well as environmental aspects. However, the ranking of these factors may vary from region to region: for example, in Brittany there are many investment clubs financing windmills. The selection criteria for the investments also take into account entrepreneurial characteristics, of which the three most important are entrepreneur's motivation, level of understanding shown by the team presenting the project, and social and solidarity motivations (Estapé-Dubreuil et al. 2012). The movement grows especially in 
times of crisis when local solidarity needs are felt more. However, ideological, motivational, institutional, and communication difficulties have kept the movement from growing further (Ashta and Hudon 2012).

One way of overcoming the high costs of diffusion of information is to use the internet. The slow money movement in the USA is regrouping investment funds which want to invest in local projects, often linked to slow food and artisans (Tasch 2009). These investments are usually patient, agricultural-related, local, and small. Thus, the objective enshrined in the CIGALES movement is being diffused today in the USA (Ashta and Bratu 2013). However, the investment funds are much larger and investing in socially and environmentally desirable projects of a larger size (Ashta 2013a). This would then be using a technological innovation (the internet) and transposing a social movement (slow food) to create a parallel innovation.

In fact, the funds registered on the slow money movement resemble largely the funds in impact investment which could be considered as related to socially responsible investments. Recognizing that there are a lot of investors who want to get an impact bang out of their investment buck, a whole new asset class of impact investments is being made to encourage investments in entrepreneurial projects which would lead to high impact all over the world (Freireich and Fulton 2009). Examples include Aavishkaar, Acumen Fund, and Root Capital. As opposed to socially responsible investments which seek near-market returns but filter out undesirable sectors, impact investors tend to be social investors seeking to get their money back with a low return to cover inflation. However, most of these impact investments are too large to finance small entrepreneurs directly and are financing instead the microfinance institutions. They are therefore close to dedicated microfinance investment vehicles, such as ResponsAbility funds or Blue Orchard which also finance microfinance institutions. Thus, innovation is more one of targeting people with noneconomic motivations to invest in socially desirable sectors.

Can technology go further than mere diffusion of information and break this barrier and allow for wider investment possibilities directly into microentrepreneur projects? Crowdfunding websites are emerging to allow small investors to participate in financing microentrepreneurial projects. Today, there are over 300 such websites with a new one being started every other day. There are 24 such websites in France alone according to the Association Financement Participatif France. While many of the crowdfunding sites are

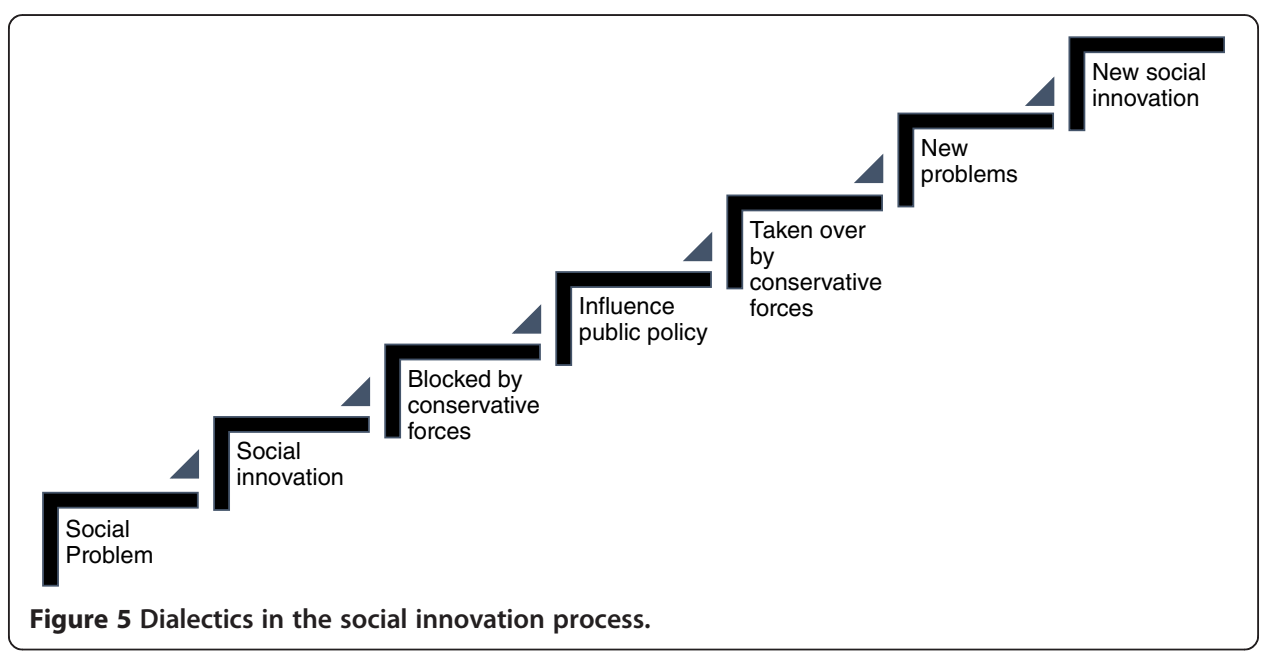


still offering only possibilities to donate (Kickstarter in the USA and MyMajorCompany in France) or lend (Kiva in the USA and Babyloan in France), some are offering possibilities to offer equity (WISEED in France). The legality of such equity offerings is not clear, but ingenious means are being taken to circumvent laws which do not allow a small entrepreneur to ask the public for equity funds without the permission of the regulatory watchdog, which wants to protect the small depositors. Clearly this is a radical innovation, specifically one of creating an ecosystem.

\section{Conclusions}

Microfinance has come out with a number of financial products to satisfy an unserved market through innovative distribution. The market was unserved because the size of the products was too large, entailing high costs and high risks for financial institutions. By reducing the size of the product and by distributing it through new channels, microfinance has effectively created an innovation. Moreover, microfinance has shown the entrepreneurial potential of the poor and their ability to create their own jobs. It is therefore an innovation that fosters entrepreneurship which allows recipients to develop a wide range of productive activities that generate revenues.

Microfinance is evolving both as a social institution as well as in utilizing new technologies such as cloud computing information systems, mobile banking, and online financing of microfinance institutions for the development of its outreach (Ashta et al. 2011). Many of the financial services being targeted to the poor, including microsavings, microinsurance, remittances, and government-to-poor payments, are based on innovative institutional creation. All of these represent areas for future research.

Our paper has presented an application to illustrate the dialectics in the social innovation process as presented in Figure 5. The entrepreneur lacked financing since the banker did not trust him. This social problem was solved by social innovations presented in microcredit. These social innovations were blocked by conservative forces at a local level. To influence public policy, the social entrepreneur therefore needs to attract public policy support, including donors and regulators. Once social innovation is proved successful, banks and other for-profits can take over the microcredit movement. However, their use of this leads to new forms of stress for the microenterpreneur. This in turn requires new social innovations to provide services such as microguarantees, microinsurance, microsavings, microremittances, and microequity.

Competing interests

The authors declare that they have no competing interests.

\section{Authors' contributions}

AA drafted the microcredit and microequity sections, MC drafted the microinsurance and microguarantee sections, ASMM drafted the microsaving and microremittances section. All authors reviewed and added to each others' sections and participated in the full paper.

\section{Author details}

${ }^{1}$ Holder of the Banque Populaire Chair in Microfinance at the Burgundy School of Business (ESC Dijon-Bourgogne),

CEREN, CERMi, 29 rue Sambin, 21000, Dijon, France. ${ }^{2}$ Université de Lomé, Togo, CERFEG, FASEG, BP 1515, Lome, Togo ${ }^{3}$ Credit and Development Forum, Bangladesh, House \# 216 (First Floor), West Dhanmondi, Madhubazar, 1209, Dhaka, Bangladesh.

Received: 23 September 2013 Accepted: 4 October 2013

Published: 14 Jan 2014

\section{References}

Adusei, M, \& Appiah, S. (2012). Evidence on the impact of the "susu" scheme in Ghana. Global Journal of Business Research (GJBR), 6(2), 1-10.

Afrin, S, Islam, N, \& Ahmed, SU. (2010). Microcredit and rural women entrepreneurship development in Bangladesh: a multivariate model. Journal of Business \& Management, 16(1), 9-36. 
Amuedo-Dorantes, C, \& Pozo, S. (2006). Remittance receipt and business ownership in the Dominican Republic. World Economy, 29(7), 939-956. doi:10.1111/j.1467-9701.2006.00830.x.

Armendàriz, B, \& Morduch, J. (2005). The economics of microfinance. Cambridge: MIT Press. Armendàriz, B, \& Morduch, J. (2010). The economics of microfinance. Cambridge: MIT Press.

Ashta, A. (2009). Microcredit capital flows and interest rates: an alternative explanation. Journal of Economic Issues, 43(3), 661-683. Ashta, A (Ed.). (2011). Advanced technologies for microfinance: solutions and challenges. Hershey: IGI Global.

Ashta, A. (2013a). An introduction to slow money and its Gandhian roots. Available at SSRN. http://ssrn.com/ abstract=2137632, accessed 28th Feb 2013.

Ashta, A. (2013b). A minimum wage solution to halving world poverty by 2015: a stakeholder approach. IIMB Management Review, 25(1), 6-18.

Ashta, A, \& Bratu, D. (2013). Slow money: un modèle alternatif pour des investissements durables. In C Vitari (Ed.), Slow management. Paris: Entreprendre la transition, Pearson.

Ashta, A, \& Bush, M. (2009). Ethical issues of NGO principals in sustainability outreach and impact of microfinance: lessons in governance from the Banco Compartamos' I P O. Management Online REview, 1-18.

Ashta, A, \& Hudon, M. (2012). The Compartamos microfinance IPO: mission conflicts in hybrid institutions with diverse shareholding. Strategic Change: Briefings in Entrepreneurial Finance, 21(7-8), 331-341.

Ashta, A, Khan, S, \& Otto, PE. (2011). Does microfinance cause or reduce suicides? Policy recommendations for reducing borrower stress. Available at SSRN: http://ssrn.com/abstract=1715442, accessed 28th Feb 2013.

Ashta, A, Dayson, K, Gera, R, Hettihewa, S, Krishna, NV, \& Wright, C. (2013). Microcredit as a social innovation. In F Moulaert, D MacCallum, A Mehmood, \& A Hamdouch (Eds.), The international handbook on social innovation (pp. 80-92). Cheltenham: Edward Elgar.

Assogba, Y. (2007). Innovation sociale et communauté, une relecture à partir des sociologues classique. série "Recherche" (pp. 17). Université du Québec en Outaouais: ARUC-ISDC.

Barlet, K. (2000). Microfinance et commercialisation: de quoi parle-t-on? (BIM, p. no 74).

Belwal, R, Tamiru, M, \& Singh, G. (2012). Microfinance and sustained economic improvement: women small-scale entrepreneurs in Ethiopia. Journal of International Development, 24, S84-S99. doi:10.1002/jid.1782.

Bhatt, N, \& Tang, S-Y. (2001). Delivering microfinance in developing countries: Controversies and policy perspectives. Policy Studies Journal, 29(2), 319-333.

Biener, C, \& Eling, M. (2011). The performance of microinsurance programs: a data envelopment analysis. Journal of Risk \& Insurance, 78(1), 83-115. doi:10.1111/j.1539-6975.2010.01404.x.

Burand, D. (2012). Beyond microfinance: creating opportunities for women at the base of the pyramid. International Trade Forum, 2, 20-21.

Chamlee-Wright, E. (2002). Savings and accumulation strategies of urban market women in Harare, Zimbabwe. Economic Development \& Cultural Change, 50(4), 979.

Chotigeat, T, Balsemeier, PW, \& Stanley, TO. (1991). Fueling Asian immigrants' entrepreneurship: a source of capital. Journal of Small Business Management, 29(3), 50-61.

Churchill, C. (2002). Trying to understand the demand for microinsurance $\angle F N R><F N R><F N>$ This article was originally presented at the Marriott School Microfinance Research Symposium The Second Microfinance Revolution: Creating Customer-Centered Microfinance. [Article]. Journal of International Development, 14(3), 381-387. doi:10.1002/jid.882.

Churchill, C. (2006). Protecting the poor: a microinsurance compendium. Geneva: ILO and Munich Re Foundation.

Churchill, C. (2007). Insuring the low-income market: challenges and solutions for commercial insurers. Geneva Papers on Risk \& Insurance - Issues \& Practice, 32(3), 401-412.

Cloutier, J. (2003). Qu'est ce que línnovation sociale? (p. pp. 43 p). Études théoriques: Cahier du CRISES.

Cohen, M, \& Sebstad, J. (2005). Reducing vulnerability: the demand for microinsurance. [Article]. Journal of International Development, 17(3), 397-474. doi:10.1002/jid.1193.

Cohen, M, McCord, MJ, \& Sebstad, J. (2005). Reducing vulnerability: demand for and supply of microinsurance in East Africa. [Article]. Journal of International Development, 17(3), 319-325. doi:10.1002/jid.1192.

Collins, D, Morduch, J, Rutherford, S, \& Ruthven, O. (2010). Portfolios of the poor: how the world's poor live on \$2 a day. Ranikhet: Permanent Black.

Copestake, J, Bhalotra, S, \& Johnson, S. (2001). Assessing the impact of microcredit: a Zambian case study. Journal of Development Studies, 37(4), 81.

Couchoro, M. (2001). Transformation des relations banques/institutions de microcrédit (IMC) au Togo. Une lecture à partir des cadres théoriques de l'innovation. Revue Economie et solidarité, 41(N 1-2), 71-87.

Couchoro, M. (2011). Microcrédit et réduction de la pauvreté, une application au cas du Togo. Sarrebruck: Les Editions Universitaires Européennes.

Daley-Harris, S. (2004). State of the Microcredit Summit Campaign report 2004. Washington, DC: Microcredit Summit Campaign.

Daley-Harris, S. (2011). State of the Microcredit Summit Campaign report 2011. Washington, DC: Microcredit Summit Campaign.

De Bruyn, T, \& Kuddus, U. (2005). Dynamics of remittance utilization in Bangladesh, IOM migration series (vol. 18). Geneva: International Organisation for Migration.

De Gobbi, MS. (2003). Mutual guarantee associations for small and micro-entrepreneurs: lessons learned from Europe and Africa. African Development Review, 15(1), 23-34. doi:10.1111/1467-8268.00060.

De Soto, H. (2000). The mystery of capital: why capitalism triumphs in the West and fails everywhere else (p. 276). London: Black Swan.

Dror, DM, \& Jacquier, C. (1999). Micro-insurance: extending health insurance to the excluded. International Social Security Review, 52(1), 71.

Dutta, D, \& Magableh, I. (2006). A socio-economic study of the borrowing process: the case of microentrepreneurs in Jordan. Applied Economics, 38(14), 1627-1640. doi:10.1080/00036840500427148.

Epstein, MJ, \& Yuthas, K. (2010). Microfinance in cultures of non-repayment. Journal of Developmental Entrepreneurship, 15(1), $35-$ 54. doi:10.1142/s1084946710001440.

Estapé-Dubreuil, G, Ashta, A, \& Hédou, J-P. (2012). Microequity and Social Entrepreneurship from a Venture Capital Perspective: A case study of the CIGALES approach to micro-equity. Strategic Change: Briefings in Entrepreneurial Finance, 21(7-8), 355-368. 
Eversole, R. (2003). Help, risk and deceit: microentrepreneurs talk about microfinance. Journal of International Development, 15(2), 179-188. doi:10.1002/jid.972.

Freireich, J, \& Fulton, K. (2009). Investing for Social and Environmental Impact - A Design for Catalyzing an Emerging Industry, Monitor Institute.

Gentil, D, \& Servet, JM. (2002). Entre "localisme" et mondialisation: la microfinance comme révélateur et comme levier de changement socio-économique. Revue Tiers monde, 172, 738-760.

Gentry, WM, \& Hubbard, RG. (2004). Entrepreneurship and household saving. Advances in Economic Analysis \& Policy, 4(1), 1-55.

Gomez, R, \& Santor, E. (2001). Membership has its privileges: the effect of social capital and neighbourhood characteristics on the earnings of microfinance borrowers. Canadian Journal of Economics, 34(4), 943.

Gunu, U. (2010). Entrepreneurship development in micro enterprises as a medium for poverty reduction in Kwara state, Nigeria. Interdisciplinary Journal of Contemporary Research in Business, 2(6), 235-252.

Hambrick, DC. (2007). The field of management's devotion to theory: too much of a good thing? Academy of Management Journal, 50(6), 1346-1352.

Hamid, SA, Roberts, J, \& Mosley, P. (2011). Evaluating the Health Effects of Micro Health Insurance Placement: Evidence from Bangladesh. World Development, 39(3), 399-411.

Hasan, RA. (2006). Harnessing remittances for economic development of Bangladesh. INAFI: Working paper series. Dhaka.

Hasan, ME, \& Iglebaek, M. (2004). Microfinance with Un-reached People in the Rural Area: Experience and Learning. In Paper presented at the Asia Pacific Regional Microcredit Summit Meeting of Councils, Dhaka, Bangladesh, 18 February 2004

Hashemi, SM. (1997). Those Left Behind: A Note on Targeting The Hardcore Poor. In GD Wood \& I Sharif (Eds.), Who Needs Credit? Poverty and Finance in Bangladesh (pp. 96-129). Dhaka and U.K. University Press Limited and Zed Books.

Hulme, D, \& Mosley, P. (1997). Finance for the poor or poorest? Financial Innovations, Poverty and Vulnerability. In GD Wood \& I Sharif (Eds.), Who Needs Credit? Poverty and Finance in Bangladesh (pp. 96-129). Dhaka and U.K: University Press Limited and Zed Books.

Karlan, D, \& Zinman, J. (2010). Expanding credit access: using randomized supply decisions to estimate the impacts. Review of Financial Studies, 23(1), 433-464. doi:10.1093/rfs/hhp092.

Karnani, A. (2007). The mirage of marketing to the bottom of the pyramid: how the private sector can help alleviate poverty. California Management Review, 49(4), 90-111.

Khan, S, \& Ashta, A. (2012). Cost control in microfinance: lessons from the ASA case. Cost Management, 26(1), 5-22.

Korosteleva, J, \& Mickiewicz, T. (2011). Start-up financing in the age of globalization. Emerging Markets Finance \& Trade, 47(3), 23-49. doi:10.2753/ree1540-496x470302.

Kwon, WJ. (2010). An Analysis of Organisational, Market and Socio-cultural Factors Affecting the Supply of Insurance and Other Financial Services by Microfinance Institutions in Developing Economies* [Article]. Geneva Papers on Risk \& Insurance - Issues \& Practice, 35(1), 130-160. doi:10.1057/gpp.2009.32.

Lawrence, TB, Suddaby, R, \& Leca, B. (2009). Introduction: theorizing and studying institutional work. In T Lawrence, R Suddaby, \& B Leca (Eds.), Institutional work: actors and agency in institutional studies of organizations (pp. 1-28). Cambridge: Cambridge University Press.

Lecomte, M. (2008). La microfinance solidaire, Revue d'Economie Financière, nº2, juin (pp. 185-193).

Lenox, MJ, Rockart, SF, \& Lewin, AY. (2007). Interdependency, competition, and industry dynamics. Management Science, 53(4), 599-615.

Leung, K. (2011). Presenting post hoc hypotheses as a priori: ethical and theoretical issues. Management \& Organization Review, 7(3), 471-479. doi:10.1111/j.1740-8784.2011.00222.x.

Lewis, JC. (2008). Microloan sharks. Stanford Social Innovation Review, 54-59.

Lianos, T, \& Pseiridis, A. (2009). On the occupational choices of return migrants. Entrepreneurship \& Regional Development, 21(2), 155-181. doi:10.1080/08985620802176187.

Maes, JP, \& Reed, LR. (2012). State of the Microcredit Summit Campaign report 2012. Washington, DC: Microcredit Summit Campaign.

Marti, I, \& Mair, J. (2009). Bringing change into the lives of the poor: entrepreneurship outside traditional boundaries. In T Lawrence, R Suddaby, \& B Leca (Eds.), Institutional work: actors and agency in institutional studies of organizations (pp. 31-58). Cambridge: Cambridge University Press.

Matul, M, McCord, MJ, Phily, C, \& Harms, J. (2009). The Landscape of Microinsurance in Africa. Microinsurance working paper 4 (pp. 54p). Geneva: International Labour Office.

Mersland, R, \& Eggen, Ø. (2007). You cannot save alone - financial and social mobilization in savings and credit groups. Available at SSRN eLibrary, http://papers.ssrn.com/sol3/papers.cfm?abstract_id=1032247, accessed Feb 28, 2013.

Mills, LF. (1996). Corporate tax compliance and financial reporting. National Tax Journal, 49(3), 421-435.

Moulaert, F, MacCallum, D, \& Hillier, J. (2013a). Social innovation: intuition, precept, concept, theory and practice. In F Moulaert, D MacCallum, A Mehmood, \& A Hamdouch (Eds.), The International Handbook on Social Innovations (pp. 13-24). Cheltenham: Edward Elgar.

Moulaert, F, MacCallum, D, Mehmood, A, \& Hamdouch, A. (2013b). General introduction: the return of social innovation as a scientific concept and a social practice. In F Moulaert, D MacCallum, A Mehmood, \& A Hamdouch (Eds.), The International Handbook on Social Innovations (pp. 1-6). Cheltenham: Edward Elgar Publishing.

Murshid, KAS, Iqbal, K, \& Ahmed, M. (2002). A study of remittance inflows \& utilization. Dhaka: International Organization for Migration.

Nouvel, D. (2004). Eléments statistiques concernant les clubs dinvestissement solidaires "Cigales" et les entreprises "cigalées". Unpublished paper. Université du Mans.

Pages, ER, \& Markley, DM. (2004). Understanding the environment for rural North Carolina (p. 61). Kansas City: Center for Rural Entrepreneurship.

Pisani, MJ, \& Yoskowitz, DW. (2004). Microcredit and micro and small enterprise development in Belize, Central America: a qualitative study of the small farmers and business bank, Ltd. Latin American Business Review, 5(1), 45. doi:10.1300/J140v05n01.03. 
Pitt, MM, Shahidur, RK, \& Cartwright, J. (2006). Empowering women with micro finance: evidence from Bangladesh. Economic Development \& Cultural Change, 54(4), 791-831.

Prahalad, CK. (2006). The fortune at the bottom of the pyramid: eradicating poverty through profits. Upper Saddle River: Wharton School Publishing.

Quadrini, V. (1999). The importance of entrepreneurship for wealth concentration and mobility. Review of Income \& Wealth, 45(1), 1-19.

Quadrini, V. (2009). Entrepreneurship in macroeconomics. Annals of Finance, 5(3/4), 295-311. doi:10.1007/s10436-0080105-7.

Rahman, HZ. (1998). Bangladesh: Dynamics of Rural Poverty (Paper presented at the International Conference on Poverty, Dhaka, Bangladesh, 9-11 February 1998).

Reed, LR. (2013). State of the Microcredit Summit Campaign report 2013. Washington, DC: Microcredit Summit Campaign.

Rhyne, E, \& Guimon, A. (2007). The Banco Compartamos initial public offering. In Accion Insight http:// centerforfinancialinclusionblog.files.wordpress.com/2011/10/the-banco-compartamos-initial-public-offering.pdf, accessed Sept 30, 2008.

Rivera, JPR, \& Reyes, PO. (2011). Remittances as avenue for encouraging household entrepreneurial activities. Journal of International Business Research, 10, 85-113.

Rosenberg, R. (2007). CGAP reflections on the Compartamos initial public offering: a case study on microfinance interest rates and profits. Washington, DC: CGAP.

Rosenberg, R, Gonzalez, A, \& Narain, S. (2009). The new moneylenders: are the poor being exploited by high microcredit interest rates? Occasional paper (vol. 15). Washington, DC: CGAP.

Russo, PD. (2007). Les CIGALES: notre épargne, levier pour entreprendre autrement. Gap:France: Éditions Yves Michel.

Rutherford, S. (1999). The poor and their money: an essay about financial services for poor people. Manchester: Institute for Development Policy and Management, University of Manchester.

Rutherford, S. (2001). The economics of poverty: how poor people manage their money. In Ideas in Development Journal: Communities Without Borders. http://media.microfinancelessons.com/resources/ Economics_poverty_rutherford.pdf, accessed 28th Feb 2013.

Sachs, JD. (2005). The end of poverty: economic possibilities for our time (p. 398). New York: Penguin Books.

Schumpeter, J. (1935). Théorie de l'évolution économique : recherches sur le profit, le crédit, l'intérêt et le cycle de la conjoncture. Paris: Dalloz.

Smith, G, \& Epstein, K. (2007). The ugly side of microlending. Business Week. http://www.businessweek.com/stories/200712-12/the-ugly-side-of-microlending, accessed on June 30, 2008.

Tasch, W. (2009). Inquiries into the Nature of Slow Money: Investing as if Food, Farms, and Fertility Mattered. Chelsea Green.

Taupin, M-T, \& Glemain, P. (2006). Les Cigales: Quelle inscription dans l'économie sociale et solidaire. (pp. 59 pages): Chapitre d'un rapport intermédiaire pour la délégation interministérielle à la cohésion sociale (ex-DIES).

Tavanti, M. (2010). Before microfinance: the social value of microsavings in Vincentian poverty reduction. Paper presented at the 17th Annual International Vincentian Business Ethics Conference. Chicago: DePaul University.

Tavanti, M. (2013). Before microfinance: the social value of microsavings in Vincentian poverty reduction. Journal of Business Ethics, 112, 697-706.

Tooley, J. (2007). Educating Amaretch: private schools for the poor and the new frontier for investors. Economic Affairs, 27(2), 37-43. doi:10.1111/j.1468-0270.2007.00728.x.

Woller, G. (2002). Assessing the community economic impact of microfinance institutions. Journal of Developmental Entrepreneurship, 7(2), 133.

Woller, GM, \& Woodworth, W. (2001). Microcredit as a grass-roots policy for international development. Policy Studies Journal, 29(2), 267-282.

Woller, GM, Dunford, C, \& Woodworth, W. (1999). Where to Microfinance. International Journal of Economic Development, 1(1), 29-64.

World Bank. (2006). Global Economic Prospects: Economic Implications of Remittances and Migration. Washington DC: The World Bank

Wydick, B. (2002). Microfinance among the Maya: tracking the progress of borrowers. Development \& Change, 33(3), 489

Yang, D. (2008). International migration, remittances and household investment: evidence from Philippine migrants' exchange rate shocks. Economic Journal, 118(528), 591-630. doi:10.1111/j.1468-0297.2008.02134.X.

Yunus, M. (2003). Banker to the poor: micro-lending and the battle against world poverty. New York: Public Affairs.

Zeller, M, \& Meyer, RL. (2002). The triangle of microfinance: financial sustainablility, outreach, and impact. Baltimore: John Hopkins University Press.

10.1186/2192-5372-3-4

Cite this article as: Ashta et al:: Dialectic evolution through the social innovation process: from microcredit to microfinance. Journal of Innovation and Entrepreneurship 2014, 3:4 